\title{
ЕНЕРГЕТИЧНА ЕФЕКТИВНІСТЬ ВИКОРИСТАННЯ ПЕРШИХ ВІД ПОВЕРХНІ ВОДОНОСНИХ ГОРИЗОНТІВ ДЛЯ ТЕПЛО- І ХЛАДОПОСТАЧАННЯ
}

\author{
Ю.П. Морозов ${ }^{1}$, доктор технічних наук, А.А. Барило르, Д.М. Чалаєв ${ }^{1,2}$, кандидат технічних наук, М.П. Добровольський ${ }^{2}$ \\ ${ }^{1}$ Інститут відновлюваної енергетики НАН України, \\ 02094,м. Київ, вул. ГнатаХоткевича, 20А \\ ${ }^{2}$ Інститут технічної теплофізики НАН України \\ 03057, м. Київ, вул. Марії Капніст (Желябова), 2а
}

На підставі експлуатаційних даних двох свердловин, пробурених на території Міжнародного центру відновлювальної енергетики, визначена енергетична ефективність використання підземних вод перших від поверхні землі водоносних горизонтів для отримання теплоти та холоду в системах теплохладопостачання житлових будинків та будівель громадського призначення. Дослідні свердловини розташовані на відстані 11,5 м одна від одної, глибина яких складає 50 і 57 м відповідно. Під час проведення пробних відкачок одержані основні попередні експлуатаційні характеристики горизонту. Статичний рівень

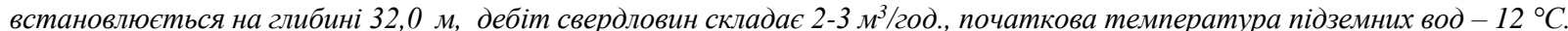

Були розкриті таки водоносні горизонти та комплекси: горизонт алювіально-делювіальних відкладень першої надзаплавноі тераси, що складається квариовими пісками з лінзами та проверстками суглинків і залягає на глибині від 8 до 12 м; водоносний комплекс у відкладах межигірської, берекської та новопетрівської світ олігоцен-міоцену (полтавська і харківська серіі), який залягає на глибині від 32 до 50 м та створений з дрібно-зернистого піску; бучаксько-канівський водоносний горизонт, щзо залягає на глибині від 90 до 117 м і складається з мілкого та дрібно-зернистого піску.

Для оцінки можливості використання підземних вод з метою геотермального тепло- $і$ хладопостачання використано водоносний горизонт полтавського і харківського віку, оскільки цей горизонт ізольований від поверхневих і грунтових вод потужною товщцою (до 20 м) щүільних глин, щуо забезпечує йому сталий режим фільтрації і стабільні гідрогеологічні параметри.

В роботі показано, що використання підземних вод як джерела низькопотенційної енергії для теплових насосів дозволяє отримати від свердловини в $7 . .10$ разів більшу теплову потужсність в порівнянні з традиційними теплонасосними системами на основі трунтових зондів. Запропоновано схему роботи теплонасосних агрегатів з ступінчастим спрацьовуванням температурного потенціалу підземних вод від $+12{ }^{\circ} \mathrm{C}$ до $+1{ }^{\circ} \mathrm{C}$, що дозволяє майже в півтора рази підвищити енергетичну ефективність процесу генерування теплової енергії. Очінено ефективність застосування підземних вод для кондииіонування примімень в літній час. Показано, що для даних свердловин величина СОР прочесу «пассивного» кондиціонування перевищує 25. Температуру в приміщенні можна знизити на 5 градусів. Кількість «холоду», яка може бути отримана від однієї свердловини, становить більше $10 \kappa$ кт.

На підставі аналізу гідрогеологічних характеристик та режиму фільтрачії перших від поверхні водоносних горизонтів вибрано найбільш придатний для створення систем геотермального тепло- $і$ холодопостачання водносний комплекс та проведено розрахунки, які показали доиільність використання водоносного горизонту у відкладах межигірської, берекської та новопетрівської світ олігоцен-міочену. Бібл. 3, табл. 3, рис. 4.

Ключові слова: підземні води, тепловий насос, теплопостачання, холодопостачання, енергетична ефективність

\section{ENERGY EFFICIENCY OF THE SHALLOW AQUIFERS UTILIZATION FOR THE DISTRICT HEATING AND COOLING}

\author{
Yu. Morozov ${ }^{1}$, Doctor of Technical Sciences, A. Barylo ${ }^{1}$, D. Chalaev ${ }^{1,2}$, candidate of technical sciences, M. Dobrovolskyi ${ }^{2}$ \\ ${ }^{1}$ Institute of Renewable Energy of the National Academy of Sciences of Ukraine \\ 02094, Kyiv, st. Hnat Hotkevich, 20A, \\ ${ }^{2}$ Institute of Technical Thermophysics of the National Academy of Sciences of Ukraine \\ 03057, Kyiv, st. Maria Kapnist (Zhelyabova), 2a
}

The energy efficiency of the groundwater ustilization from the shallow s to obtain heat and cold in the heating and cooling systems of residential buildings and public buildings was determined. The calculations are based on the operational data from two wells drilled on the territory of the International Renewable Energy Center. Experimental wells are located at a distance of $11.5 \mathrm{~m}$ from each other, the depth of which is 50 and $57 \mathrm{~m}$, respectively. During the holding of the test pumping, the main preliminary operational aquifer characteristics were obtained. The static level is set at a depth of $32.0 \mathrm{~m}$, the flow rate of wells is $2-3 \mathrm{~m}^{3} / \mathrm{h}$., the initial temperature of groundwater is $12^{\circ} \mathrm{C}$.

The following aquifers and complexes were discovered: the alluvial-deluvial horizon of the first above-flood terrace terrain, consisting of quartz sand with lenses and layers of loam and lying at a depth of 8 to $12 \mathrm{~m}$; the aquiferous complex in the sediments of the Mezhigorskaya, Berek and Novopetrovsky formations of the Oligocene-Miocene (Poltava and Kharkiv series), which lies at a depth of 32 to $50 \mathrm{~m}$ and consists of fine-grained sand; Buchak-Kanev aquifer, occurring at a depth of 90 to $117 \mathrm{~m}$ and consisting of fine and fine-grained sand.

In order to evaluate the possibility of groundwater using for geothermal heat and cold supply, an aquifer of Poltava and Kharkiv age is used, since this horizon is isolated from surface and groundwater by a thick layer (up to $20 \mathrm{~m}$ ) of dense clays, provides it with a permanent filtration mode and stable hydrogeological parameters.

(C) Ю.П. Морозов, А.А. Барило, Д.М. Чалаєв, М.П. Добровольський, 2019 
The work shows that the use of groundwater as a source of low-potential energy for heat pumps makes it possible to obtain from the well $7 . .10$ times more thermal power compared to traditional heat pump systems based on ground probes. A scheme of operation of heat pump units with stepwise activation of the temperature potential of groundwater from $+12{ }^{\circ} \mathrm{C}$ to $+1{ }^{\circ} \mathrm{C}$ is proposed, which makes it possible to increase the energy efficiency of the thermal energy generation process by almost one and a half times. The effectiveness of the use of groundwater for air conditioning in the summertime has been evaluated. It is shown that for these wells, the COP value of the "passive» conditioning process exceeds 25. The temperature in the room can be reduced by 5 degrees. The amount of «cold» that can be obtained from one well is more than $10 \mathrm{~kW}$.

Based on the analysis of hydrogeological characteristics and filtering mode of the first aquifers from the surface, the most suitable complex for creating geothermal heat and cold supply systems was the water complex and calculations were carried out that showed the feasibility of using the aquifer in the oligoran, berek and novopetrovsky suite deposits. Ref. 3, tabl. 3, fig. 4

Keywords: shallow aquifers, heat pump, heat supply, cold supply, energy efficiency

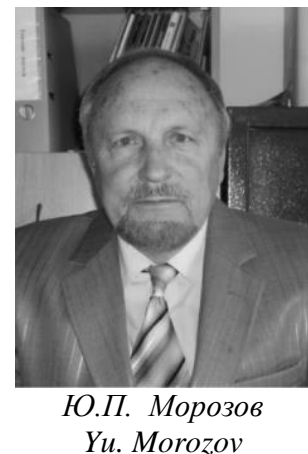

Yu. Morozov

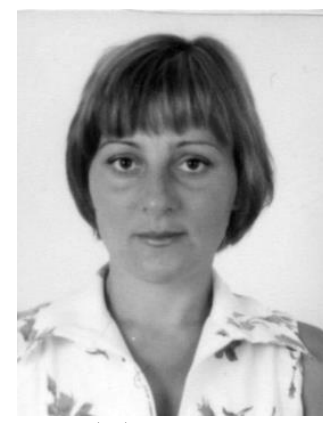

A.А. Барило A. Barylo

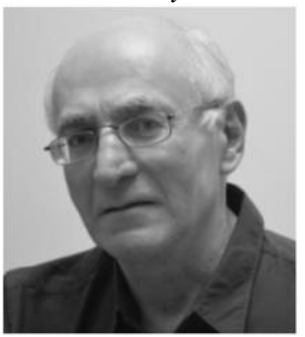

Д.М. Чалаєв

D. Chalaev

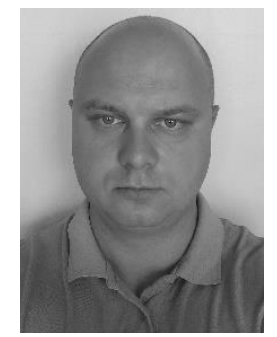

M.П. Добровольський M. Dobrovolskyi
Відомості про автора: зав. відділом геотермальної енергетики Інституту відновлюваної енергетики НАН України, доктор технічних наук, старший науковий співробітник.

Освіта: Національний технічний університет України «Київський політехнічний інститут імені Ігоря Сікорського».

Наукова сфера: відновлювана енергетика, геотермальна енергетика, використання тепла довкілля.

Публікації: більше 160.

ORCID: 0000-0003-1632-9735

Контакти: тел./факс +38 (044) 206-28-09

e-mail: geotherm@ukr.net

Відомості про автора: науковий співробітник відділу геотермальної енергетики, Інститут відновлюваної енергетики НАНУ.

Освіта: Київський національний університет імені Тараса Шевченка за спеціальністю гідрогеологія та інженерна геологія (1990 р).

Наукова сфера: геотермальні джерела енергії. Публікації: більше 25, в тому числі 2 державних стандарти.

ORCID: 0000-0001-7981-6464

Контакти: тел./факс +38 (044) 206-28-09

e-mail: geotherm@ukr.net

Відомості про автора: Старший науковий співробітник відділу геотермальної енергетики Інституту відновлюваної енергетики НАН України, кандидат технічних наук. Провідний науковий співробітник відділу тепломасообміну в дисперсних системах Інституту технічної теплофізики НАН України.

Освіта: Московський технологічний інститут м'ясної і молочної промисловості.

Наукова сфера: відновлювані джерела енергії, теплові насоси, енергозбереження.

Публікації: більше 100.

ORCID: 0000-0002-5154-4257

Контакти: тел.+38 (044) 209-07-68

e-mail: chalaev@i.ua

Відомості про автора: аспірант Інституту технічної теплофізики НАН України

Освіта: Київський національний університет будівництва та архітектури.

Наукова сфера: відновлювана енергетика, використання тепла довкілля, теплоенергетика. Публікації: 1.

ORCID: 0000-0001-9140-5158

Контакти: тел./факс +38 (066) 950-27-56

e-mail: Dobrik316@gmail.com
Author information: Head of the Department of Geothermal Energy of the Institute of Renewable Energy of the National Academy of Sciences of Ukraine, doctor of technical sciences, senior researcher.

Education: National Technical University of Ukraine "Igor Sikorsky Kyiv Polytechnic Institute"

Research area: renewable energy, geothermal energy, use of warm environment.

Publications: more than.

ORCID: 0000-0003-1632-9735

Contacts: phone/fax +38 (044) 206-28-09

e-mail: geotherm@ukr.net

Information about the author: Researcher at the geothermal energy department, Renewable Energy Institute of the NAS of Ukraine.

Education: Taras Shevchenko National University of Kyiv, hydrogeologist and engineering geologist (1990).

Research area: geothermal energy.

Publications: more than 25 including 2 state standards.

ORCID: 0000-0001-7981-6464

Контакти: тел./факс +38 (044) 206-28-09

e-mail: geotherm@ukr.net

Author information: Senior Researcher of the Department of Geothermal Energy of the Institute of Renewable Energy of NAS of Ukraine, Ph.D. (engineering). Leading Researcher of the Department of Heat and Mass Transfer in Disperse Systems of the Institute of Engineering Thermophysics of NAS of Ukraine.

Education: Moscow Technological Institute of Meat and Dairy Industry.

Research area: renewable energy sources, heat pumps, energy saving.

Publications: more than 100 .

ORCID: 0000-0002-5154-4257

Contacts: phone +38 (044) 209-07-68

e-mail: chalaev@i.ua

Author information: postgraduate student of the Institute of Engineering Thermophysics of NAS of Ukraine

Education:Kyiv National University of Construction and Architecture.

Research area: renewable energy, use of warm environment, heat power engineering.

Publications: 1 .

ORCID: 0000-0001-9140-5158

Contacts: phone/fax +38 (066) 950-27-65

e-mail: Dobrik316@gmail.com 
Дослідження ефективності використання підземних вод перших від поверхні водоносних проводимо на підставі експлуатаційних даних свердловин № 1 та № 8, пробурених на території Міжнародного центру відновлюваної енергетики та трансферу технологій (м. Київ, вул. Метрологічна, 48-50). Гідрогеологічний розтин ділянки та конструкції свердловин наведено на рис. 1.
Робота проводиться в рамках виконання наукового проекту «Розробити науковотехнічні засади перетворення та акумулювання енергії відновлюваних джерел енергії для забезпечення споруд громадського призначення» за рахунок коштів бюджетної програми «Підтримка розвитку пріоритетних напрямів наукових досліджень».

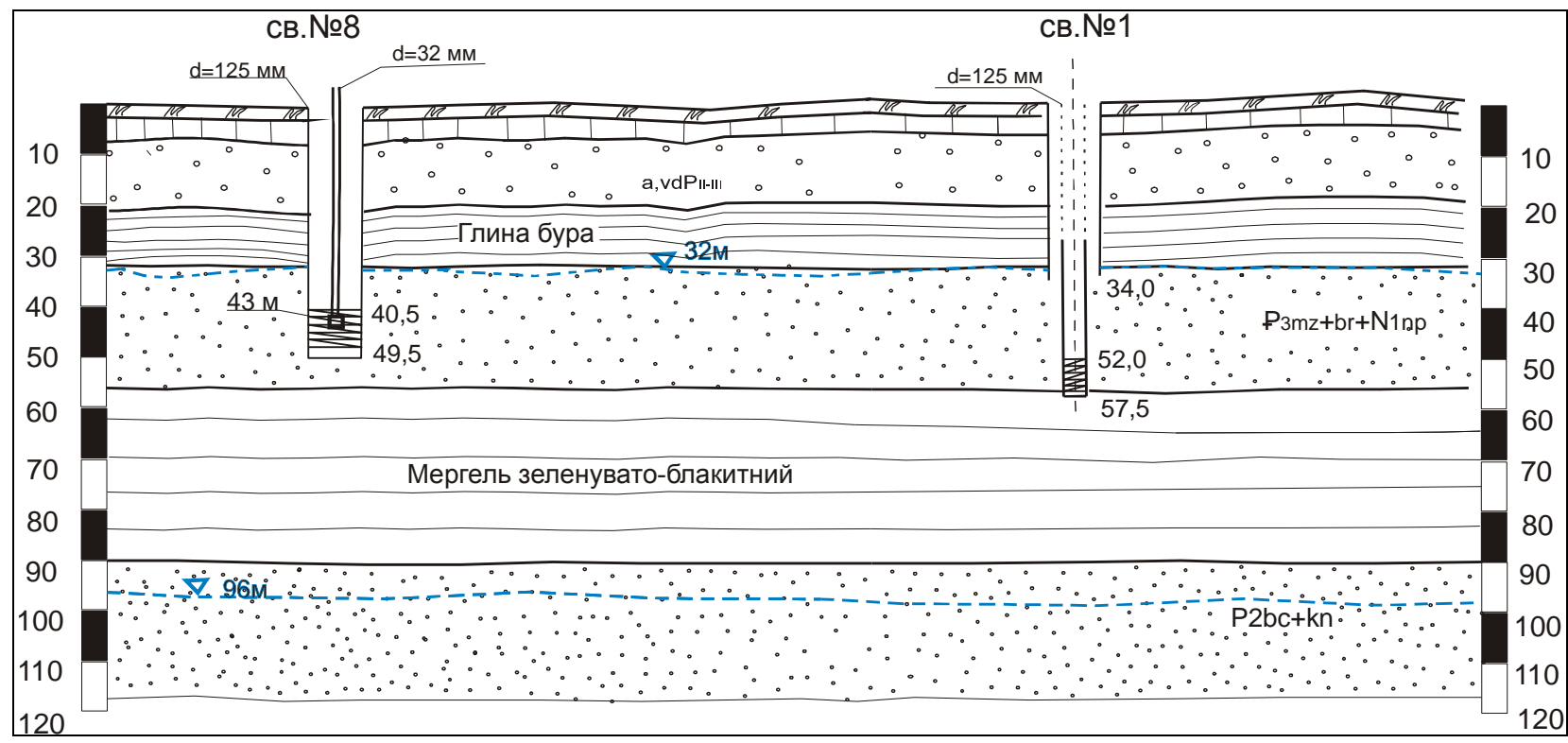

Рис. 1 Схема геологічного розтину і розташування свердловин експериментальної ділянки

Fig. 1 Scheme of geological section and location of wells of the experimental plot

В геологоструктурному відношенні ділянка дослідження розташована в межах північносхідного пологого схилу Українського щита, що занурюється під область Дніпровсько-Донецької западини. Земні надра в цьому районі мають двоповерхову будову: нижній поверх - кристалічний фундамент, що складається 3 кристалічних і метаморфічних порід докембрію, верхній поверх $\epsilon$ потужною (до 400 м) товщою палеозойських, мезозойських і кайнозойських осадових порід[1].

Сприятливі умови водообміну на пологому схилі кристалічного щита створили можливість для утворення зони прісних підземних вод, що охоплює весь розріз осадової товщі. Практичне значення мають водоносні горизонти і комплекси, приурочені до юрських, сеноманських, бучацькоканівських і харківсько-полтавських відкладень.

На ділянці дослідження під час проведення бурильних робіт від поверхні землі були розкриті таки водоносні горизонти:

1. Алювіально-делювіальні відклади першої надзаплавної тераси - кварцові піски з лінзами та проверстками суглинків. Цей горизонт, так звана «верховодка», має сезонний характер і дуже залежить від кількості атмосферних опадів. Залягає на глибині від 8 до 12 м.

2. Водоносний горизонт у відкладах межигірської, берекської та новопетрівської світ олігоцен-міоцену (полтавська і харківська серіі). Залягає на глибині від 32 до 50 м. Складається 3 сірого дрібно-зернистого піску, що перекритий потужною товщою (до 20 м) строкатих глин неогену. Статичні рівні встановлюються на глибині крівлі горизонту, тобто горизонт напірно-безнапірний.

3. Бучаксько-канівський водоносний горизонт залягає на глибині від 90 до 117 м, складається мілким та дрібно-зернистим піском. Горизонт сильно виснажений через активне використання його для водопостачання і для господарських цілей. Статичні рівні встановлюються на відмітках 96 м, тобто верхня частина горизонту «суха», горизонт безнапірний.

Свердловина № 1 була пробурена до глибини 57 м, діаметр буріння склав 215 мм. Свердловина має двохколонну конструкцію. Перша обсадна колона з НПВХ має діаметр 125 мм та встановлена в інтервалі глибин від поверхні землі до 36 м. В середині іï в інтервалі глибин 23-57 м встановлена друга колона 3 того ж матеріалу та діаметром 50 мм, яка закінчується сітчастим поліпро- 
піленовим фільтром, довжиною 5,5 м.

Свердловина № 1 розкрила водоносний горизонт у відкладах межигірської, берекської та новопетрівської світ олігоцен-міоцену (полтавська і харківська серії). Складається горизонт 3 дрібнозернистих пісків, що залягають в інтервалі глибин 34-57 м. Під час буріння було встановлено, що верхня частина горизонту «суха», статичний рівень розташований на глибині 21 м, тобто горизонт є безнапірним.

Свердловина № 8 була пробурена на відстані 11,5 м від свердловини № 1. Глибина свердловини - 50 м, а діаметр буріння - 215 мм. Свердловина по всій глибині закріплена обсадними трубами діаметром 125 мм, в інтервалі глибин 40,5-49,5 м встановлений поліпропіленовий фільтр такого ж діаметру. Нижня частина свердловини обладнана відстійником завдовжки 0,5 м з заглушкою з нПВХ.

У середині свердловини на водопідйомних трубах діаметром 32 мм на глибині 43 м встановлений електрозанурювальний насос марки Водолій 80.

Продуктивний водоносний горизонт відкла день межигірської, берекської та новопетрівської світ олігоцен-міоцену у свердловині № 8 розташований на глибині $32-50$ м. Водовмісні породи представлені піском тонко- та дрібнозернистим світло сірим. Статичний рівень встановлений на глибині 32,0 м, тобто збігається 3 покрівлею горизонту.

Для визначення попередніх величин продуктивності і приємистості межигірського, берекського та новопетрівського водоносного комплексу були проведені такі дослідно-фільтраційні випробування: в свердловині № 1 - пробний налив води 3 дебітом 2 м³/год; в свердловині № 8 - пробна відкачка. Продуктивність свердловини № 8 під час пробної відкачці становила $3,5 \mathrm{~m}^{3} /$ год із зниженням рівня у водоносному горизонті 9,0 м. Температура підземних вод $-12{ }^{\circ} \mathrm{C}$

Згідно 3 [2], водоносний комплекс у відкладах межигірської, берекської та новопетрівської світ олігоцен-міоцену в межах Дніпровсько-донецького артезіанського басейну має повсюдне поширення та характеризується наступними узагальненими гідрогеологічними параметрами:

Таблиця 1. Зведені параметри водоносного комплексу у відкладах межигірської, берекської та новопетрівської світ олігоцен-міоцену

Table 1. Summary parameters of the aquifer complex in the deposits of the mezhigirska, berekiska and newpetrivskaya world of oligocene-miocene

\begin{tabular}{|l|l|c|}
\hline \multicolumn{1}{|c|}{ № } & \multicolumn{1}{|c|}{ Параметр } & Величина \\
\hline 1 & Товщина горизонту,м & $30-50$ \\
\hline 2 & Глибина покрівлі від поверхні землі,м & від 5-9 до 40-50 \\
\hline 3 & Глибина залягання рівня води від поверхні землі,м & від1-3 до 40 \\
\hline 4 & Напір над покрівлею, м & $0,0006-0,4$ \\
\hline 5 & Питомий дебіт водоприпливів дм ${ }^{3} / \mathrm{c}$ & $0,001-10$ \\
\hline 6 & Коефіцієнт фільтрації, м/добу & $0,5-2,2 ;$ до 9 \\
\hline 7 & Мінералізація, г/дм ${ }^{3}$ & \\
\hline
\end{tabular}

Водоносний комплекс зараз широко використовується для водозабезпечення окремих сільських населених пунктів. Він характеризується локальним забрудненням $\mathrm{NH}_{4}, \mathrm{Br}, \mathrm{Fe}, \mathrm{F}$ та іншими елементами.

На теперішній час найбільш широке використання теплоти верхніх шарів Землі здійснюється за допомогою теплонасосних систем типу «грунт-вода», в яких видобування теплоти грунту здійснюється 3 застосуванням підземних горизонтальних трубних теплообмінників або Uподібних вертикальних зондів, в яких циркулює проміжний теплоносій, що переносить низькопотенційне тепло в контур випарника теплового насоса. Перевагою таких систем є повсюдна доступність джерела тепла і стабільність його температури незалежно від сезону і часу доби.

Разом 3 тим, грунтові теплообмінники мають ряд недоліків, основним 3 яких є мала величина теплозйому, що викликано низькою теплопровідністю грунтового масиву. Залежно від складу i вологості порід питомийтеплозйом 3 одного погонного метра грунтового теплообмінника складає від 20 Вт/м до 80 Вт/м [3]. Відповідно, при опалювальної площі будинку $100 \mathrm{~m}^{2}$, для роботи теплового насоса потрібно 3-4 вертикальних грунтових теплообмінника довжиною до $50 \mathrm{~m}$. Витрати на буріння таких свердловин i ïx облаштування U-подібними вертикальними зондами можуть сягати 2/3 від вартості всієї теплонасосної системи.

У даній ситуації перспективним рішенням $\epsilon$ використання в якості джерела низькопотенційної теплоти підземних вод. В Україні на зазначених глибинах (50-100 м) практично повсюдно є підземні води непитного якості, які можна використовувати для роботи теплових насосів типу «вода-вода». Для використання підземних 
вод в якості джерела низькопотенційної енергії достатньо двох свердловин. 3 однієї свердловини вода викачується свердловинним насосом, подається у випарник теплового насоса i охолоджується, після чого охолоджена незабруднена вода повертається в підземний горизонт через другу свердловину.

Для вивчення енергетичних характеристик такої системи теплопостачання нами створено дослідний стенд, який містить дві свердловини глибиною 49,5 м і 57,5 м.Експерименти 3 визначення дебіту свердловин показали, що при відкачці 3 першої свердловини 2 м³/год води за допомогою насосу статичний рівень стабілізується на величині 32 м і 34 м.

Для порівняння систем нагріву на основі ТНУ $з$ традиційними системами теплопостачання застосовують показник ефективності використання первинного палива. За цим показником гранню конкурентоспроможності установок теплонасосного теплопостачання $є \mathrm{COP}<3$, тому що для вироблення теплоти за допомогою теплового насоса використовується електрична енергія, яка, в свою чергу, виробляється при спалюванні палива 3 к.к.д. близько $30 \%$.

Підвищення ефективності ТНУ за рахунок вдосконалення їх робочих циклів і схем складає основу сучасних досліджень в області теплонасосних технологій. Залежно від температури термальної води на вході у випарник теплового насоса можливі різні варіанти його підключення. Правильний вибір схеми підключення і режимів роботи теплового насоса значною мірою визначає ефективність установки.

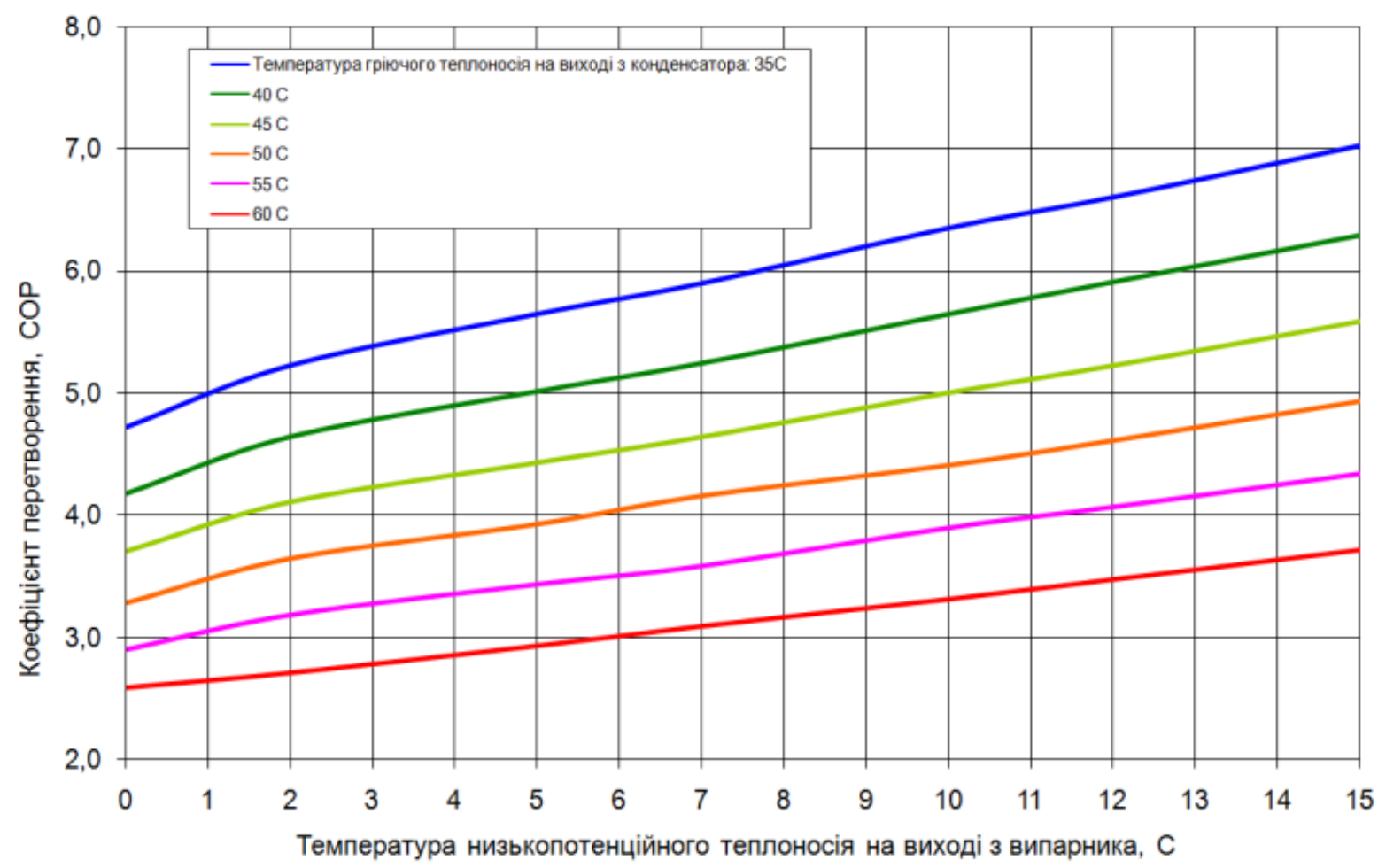

Рис. 2. Значення дійсного коефіцієнта перетворення теплового насоса HYDROCIAT на робочому тілі R134a [4].

Fig. 2. The value of the actual conversion factor of the heat pump HYDROCIAT on the working body R134a [4].

Енерговитрати на привід теплового насоса характеризуються величиною коефіцієнта перетворення і залежать в основному від співвідношення температур кипіння і конденсації холодоагенту (рис. 2). Чим менше перепад температур між випарником i конденсатором, тим нижче енерговитрати. Тому, при глибокому захолоджуванні термальної води доцільно спрацьовувати iii температуру поступово за допомогою декіль- кох послідовно встановлених ТНУ. Така робота теплових насосів, поряд зі зниженням енерговитрат на вироблення теплоти, забезпечує можливість регулювання продуктивності установки в широкому діапазоні потужностей.

1. Схема роботи теплових насосів 3 паралельною подачею води, що нагрівається, в конденсатори і послідовним проходженням низькопотенційної термальної води через випарники (рис.3). 


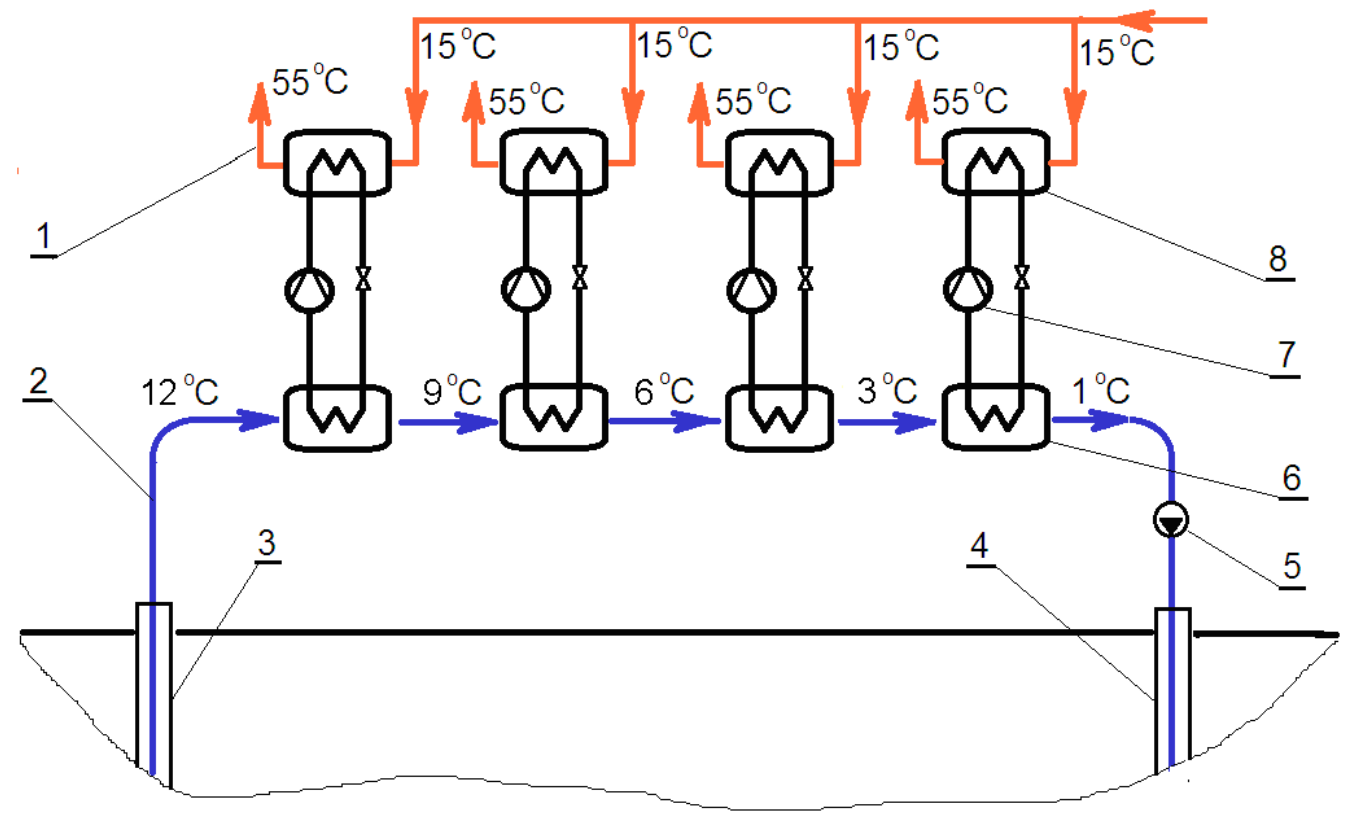

Рис. 3. Схема теплонасосної установки з паралельним підключенням конденсаторів: 1 - гаряча вода; 2 - низькопотенційна термальна вода; 3,4-видобувна і нагнітальна свердловини; 5 -насос; 6 -випарник теплового насоса; 7 - компресор; 8 - конденсатор теплового насоса.

Fig. 3. Scheme of heat pump installation with parallel connection of capacitors: 1 -hot water; 2 -low-temperature thermal water; 3.4 -extraction and injection wells; 5 - pump; 6 - heat pump evaporator; 7 -compressor; 8 - heat pump condenser.

Кількість гарячої води, яка може бути отримана в кожній ступені ТНУ, визначається з умови:

$$
C O P=\frac{Q_{k \partial}}{Q_{\kappa и}}=\frac{Q_{\kappa \partial}}{Q_{\kappa \partial}-Q_{o}},
$$

де $Q_{o}=c_{p} \rho G_{T}\left(t_{T 1}-t_{T 2}\right)-$ низькотемпературна теплота, підведена до випарника; $Q_{\kappa \partial}=c_{p} \rho G_{s}\left(t_{62}-t_{61}\right)-$ теплота, відведена від конденсатора; $c_{p}$ - теплоємність води; $\rho$ - густина води; $\left(t_{T 1}-t_{T 2}\right)-$ зниження температури термальної води в випарнику; $\mathrm{G}_{\mathrm{T}}$ - витрата термальної води через випарник; $\left(t_{62}-t_{61}\right)$ - нагрів води в конденсаторі; $\mathrm{G}_{\mathrm{B}}$ - витрата води, що нагрівається; COP коефіцієнт перетворення теплового насоса.

Поточне значення СОР в кожній ступені ТНУ визначається за характеристикоютеплонасосного агрегату (рис. 1) виходячи 3 температури води на виході з випарника і конденсатора.

Розрахункові величини СОР при послідовному відборі теплоти (з кроком в $3^{\circ} \mathrm{C}$ ) від низькопотенційного теплоносія наведені в таблиці 2.

Таблиця 2. Розрахункові величини СОР при послідовному відборі теплоти від низькопотенційного теплоносія

Table 2. Estimated values of COP for consistent selection of heat from low-temperature coolant

\begin{tabular}{|c|c|c|c|c|}
\hline $\begin{array}{c}\text { Температура води на виході з випарни- } \\
\text { ка ТНУ }\end{array}$ & \multicolumn{2}{|c|}{ Температура води на виході з конденсатора } & $\begin{array}{c}\text { Коефіцієнт перетворення } \\
\text { ТНУ }\end{array}$ \\
\hline початкова, ${ }^{\circ} \mathrm{C}$ & кінцева, ${ }^{\circ} \mathrm{C}$ & початкова, ${ }^{\circ} \mathrm{C}$ & кінцева, ${ }^{\circ} \mathrm{C}$ & 3,80 \\
\hline 12 & 9 & 15 & 55 & 3,51 \\
\hline 9 & 6 & 15 & 55 & 3,26 \\
\hline 6 & 3 & 15 & 55 & 3,11 \\
\hline 3 & 1 & 15 & 55 & 3,42 \\
\hline
\end{tabular}

Як бачимо, дана схема роботи ТНУ дозволяє в 1,1 рази $(3,42 / 3,11)$ збільшити середній за цикл СОР і знизити енерговитрати на привід теплового насоса в порівнянні 3 од- ноступеневою процесом.

Теплова потужність експериментальної свердловини при такій схемі підключення теплових насосів становить 


$$
\begin{aligned}
Q_{\kappa \partial} & =\frac{C O P_{c p}}{C O P_{c p}-1} \cdot Q_{o}=\frac{C O P_{c p}}{C O P_{c p}-1} \cdot c_{p} \rho G_{T}\left(t_{T 1}-t_{T 2}\right)= \\
& =\frac{3,42}{3,42-1} \cdot 4,2 \cdot 1 \cdot 0,56 \cdot(12-1)=36,56 \kappa \mathrm{KT},
\end{aligned}
$$

де $G_{T}=0,56$ л/сек - дебіт свердловини.

Потужність, що споживається компресором теплового насосу

$$
Q_{\kappa и}=\frac{Q_{\kappa \partial}}{C O P_{c p}}=\frac{36,56}{3,42}=10,69 \text { кВт. }
$$

Потужність, що споживаєтьсяпогружним свердловинним насосом

$$
Q_{\text {нас }}=\frac{\rho \cdot g \cdot G_{T} \cdot H}{\eta}=\frac{1 \cdot 9,8 \cdot 0,56 \cdot 50}{0,6}=457 \mathrm{BT},
$$

де $H=50$ м - необхідний напір насосу; $\eta=0,6-$ ККД насосу.

2. Схема роботи теплових насосів 3 послідовним проходженням потоків теплоносія випарники і конденсатори (рис. 4).

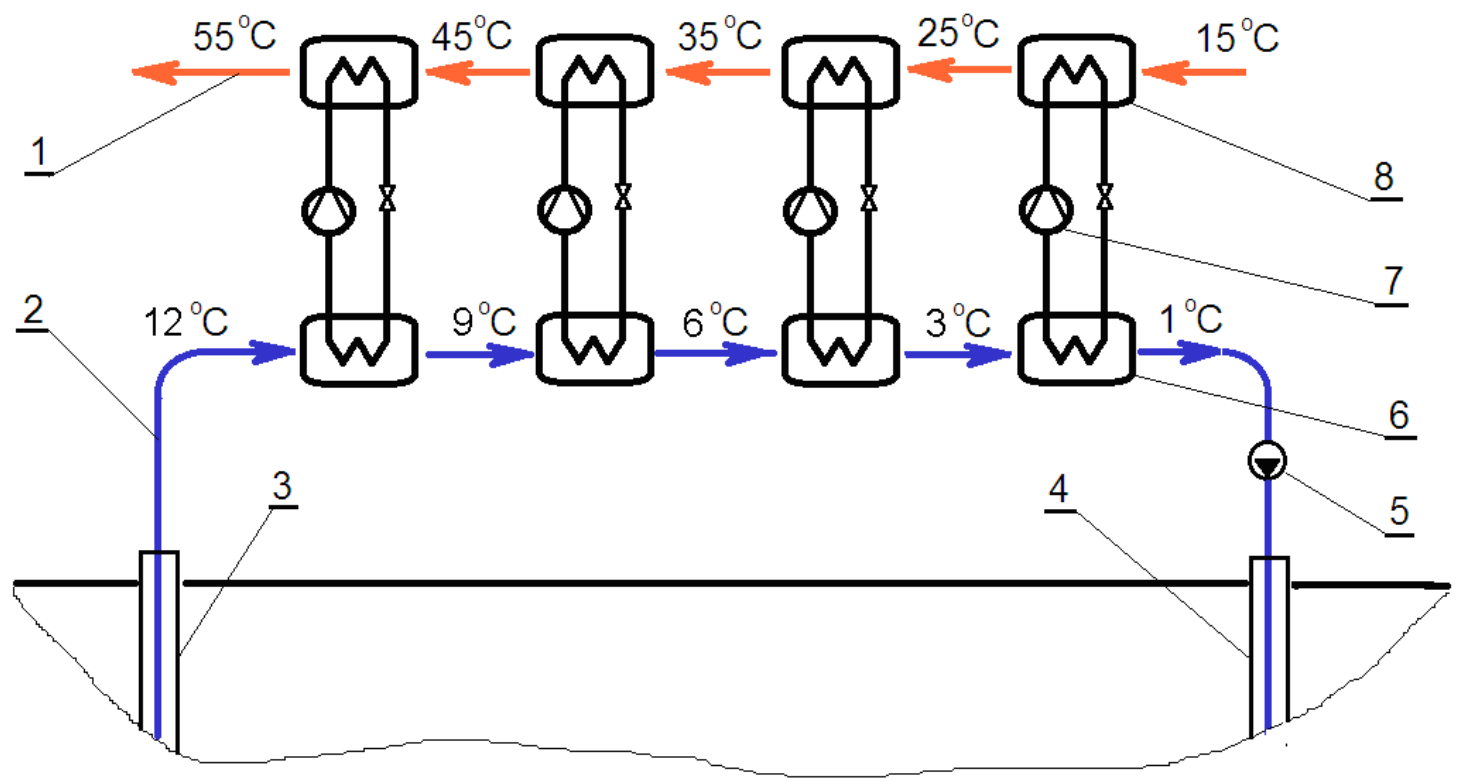

Рис. 4. Схема теплонасосної установки з послідовним підключенням конденсаторів: 1 - гаряча вода; 2 - низькопотениійна термальна вода; 3,4 - видобувна і нагнітальна свердловини; 5 -насос; 6-випарник теплового насоса; 7 - компресор; 8 - конденсатор теплового насоса.

Fig. 4. Scheme of heat pump installation with serial connection of capacitors: 1 -hot water; 2 -low-temperature thermal water; 3, 4-extraction and injection wells; 5 - pump; 6-heat pump evaporator; 7 -compressor; 8 - heat pump condenser.

Дана схема організації протитоку в апаратах ТНУ дозволяє створювати практично рівний температурний напір між випарником і конденсатором i, відповідно, підтримувати однакові режими роботи у всіх ступенях установки. Розрахункові величини СОР при роботі за схемою послідовного ступеневої зміні температур у випарник i конденсаторах ТНУ наведені в таблиці 3.

Таблиця 3. Розрахункові величини СОР при роботі за схемою послідовного ступеневої зміні температур у випарник і конденсаторах ТНУ

Table 3. Estimated values of COP when working under the scheme of successive step change in temperature in the evaporator and condensers of heat pump plants

\begin{tabular}{|c|c|c|c|c|}
\hline \multicolumn{2}{|c|}{$\begin{array}{c}\text { Температура води } \\
\text { у випарнику ТНУ }\end{array}$} & \multicolumn{2}{|c|}{$\begin{array}{c}\text { Температура води } \\
\text { в конденсаторі ТНУ }\end{array}$} \\
\hline початкова, ${ }^{\circ} \mathrm{C}$ & кінцева, ${ }^{\circ} \mathrm{C}$ & початкова, ${ }^{\circ} \mathrm{C}$ & кінцева, ${ }^{\circ} \mathrm{C}$ & 3,80 \\
\hline 12 & 9 & 45 & 55 & 4,54 \\
\hline 9 & 6 & 35 & 35 & 5,37 \\
\hline 6 & 3 & 25 & 25 & 6,35 \\
\hline 3 & 1 & 15 & & 5,02 \\
\hline
\end{tabular}


Дана схема роботи ТНУ є найбільш ефективною і дозволяє підвищити енергетичну ефективність установки майже в півтора рази в порівнянні $з$ циклом, при якому охолоджується низькопотенційне джерело від $12{ }^{\circ} \mathrm{C}$ до $1{ }^{\circ} \mathrm{C}$ і нагрів гарячої води від $15{ }^{\circ} \mathrm{C}$ до $55{ }^{\circ} \mathrm{C}$ здійснюється в один етап.

Теплова потужність експериментальної свердловини при такій схемі роботи теплових насосів

$$
\begin{aligned}
Q_{\kappa \partial} & =\frac{C O P_{c p}}{C O P_{c p}-1} \cdot Q_{o}=\frac{C O P_{c p}}{C O P_{c p}-1} \cdot c_{p} \rho G_{T}\left(t_{T 1}-t_{T 2}\right)= \\
& =\frac{5,02}{5,02-1} \cdot 4,2 \cdot 1 \cdot 0,56 \cdot(12-1)=32,31 \mathrm{\kappa BT} .
\end{aligned}
$$

Потужність, що споживається компресором теплового насосу

$$
Q_{\kappa u}=\frac{Q_{\kappa \partial}}{C O P_{c p}}=\frac{32,31}{5,02}=6,44 \mathrm{\kappa BT} .
$$

Потужність, що споживаєтьсязанурювальним свердловинним насосом в обох схемах роботи однакова і дорівнює 0,457 кВт.

Таким чином, розрахунки показують, що система утилізації теплоти приповехневихгрунтових вод з використанням свердловин глибиною 20-40 м дозволяє значно збільшити теплозйом в порівнянні з грунтовим зондом аналогічної глибини.

Крім того, в літній час грунтові води можуть використовуватися для так званого «пасивного» кондиціонування. При цьому вода зі свердловини 3 температурою $10-12^{\circ} \mathrm{C}$ безпосередньо подається в фанкойли системи кондиціонування будівлі i забезпечує охолодження приміщень.

Кількість «холоду», яка може бути отримано від однієї свердловини, становить

$$
\begin{gathered}
Q_{o=}=c_{p} \rho G_{T}\left(t_{T 1}-t_{T 2}\right)= \\
=4,2 \cdot 1 \cdot 0,56 \cdot(17-12)=11,76 \mathrm{\kappa BT} .
\end{gathered}
$$

Енергетична ефективність процесу «пасивного» кондиціювання:

$$
\text { COP }
$$

Висновки. 1. Приповерхневі грунтові води $\epsilon$ ефективним джерелом низькопотенційного тепла для теплових насосів, оскільки їх температура протягом всього року знаходиться в діапазоні від +8 до $+12{ }^{\circ} \mathrm{C}$.

2. При утилізації теплоти грунтових вод 3 використанням свердловин глибиною 20-40 м досягається 7...10 кратне збільшення теплозйому в порівнянні $з$ традиційними грунтовими теплообмінниками аналогічної глибини.
3. Додатковою перевагою використання грунтових вод $є$ можливість їх застосування для «пасивного» кондиціонування в літній час. При цьому вода зі свердловини 3 температурою близько $10{ }^{\circ} \mathrm{C}$ напряму подається до фанкойлів системи кондиціонування будівлі, що забезпечує процес охолодження 3 показником СОР 25 та більше.

4. Запропонована схема роботи ТНУ 3 послідовною ступінчатою утилізацією теплоти грунтових вод дозволяє майже в півтора рази підвищити енергетичну ефективність процесу генерування теплової енергії.

1. Арчакова С.Г., Переверзєв С.І. Державна геологічна карта України. Масштаб 1:200000 Дніпровсько-Донецька серія М-36-XXIX (Кобеляки) : Звіт ДНВП «Геоінформ України», 2014 - кн. 1-6.

2. Расовський В. М. Гідрогеологічне та інженерногеологічне довивчення масштабу 1:200 000 території аркушу M-36-XIII (Київ) : Звіт ДРГП «Північгологія», Комплексна гідрогеологічна партія, 2001 р. - кн.1-4 .

3. Морозов Ю.П.Добыча геотермальных ресурсов и аккумулирование теплоты в подземных горизонтах: [Монография] / Ю.П. Морозов. - Киев: Наукова думка, 2017. - 198 с.

4. URL: https://www.ciat.uk.com/wpcontent/uploads/2017/02/Hydrociat-LW-information-manual.pdf

\section{REFERENCES}

1. Archakova E.G., Pereverzev C.I. Derzhavna geologicheskaya karta Ukrainy/Masshtab 1: 200000 Dneprovsko- donetzka seria M-36- XXIX (Kobelyaki) [State geological map of Ukraine. Scale 1:200000 Dnieper-Donetsk series M-36-XXIX (Kobelyaki) : Zvit DRGP «Pivnichgeologiya»SI Report of SSPE "Geoinform of Ukraine]. 2014. v. 1-6. [in Ukrainian].

2. Rasovskiy V.M. Gidrogeologichne ta inzhenerno- geologichne dovchannya masszshtabu 1: 200000 teritorii arkushu M-36-XIII (Kyiv). [Hydrogeological and engineering-geological study of scale 1: 200,000 pages of M-36-XIII (Kyiv): Report of DRGP «Pivnichgeologiya», Comlex hydrogeological party]. 2001.v. 1-4. [in Ukrainian].

3. Morozov Yu.P. Dobyicha geotermalnyih resursov i akkumulirovanie teplotyi $\mathrm{v}$ podzemnyih gorizontah. [Dobycha geothermal resources and accumulation of heat in the underground horizons]. Monograph. Kyiv. Naukova Dumka.2017. 198 p. [in Russian].

4. Retrieved from https://www.ciat.uk.com/wpcontent/uploads/2017/02/Hydrociat-LW-information-manual.pdf [in English].

\section{ЭНЕРГЕТИЧЕСКАЯ ЭФФЕКТИВНОСТЬ ИСПОЛЬЗОВАНИЯ ПЕРВЫХ ОТ ПОВЕРХНОСТИ ВОДОНОСНЫХ ГОРИЗОНТОВ ДЛЯ ТЕПЛО- И ХЛАДОСНАБЖЕНИЯ}

Ю.П. Морозов ${ }^{1}$, док. техн. наук, А.А. Барило ${ }^{1}$, Д.М. Чала$\mathbf{e B}^{1,2}$, канд. техн. наук, М.П. Добровольский ${ }^{2}$

${ }^{1}$ Институт возобновляемой энергетики НАН Украины, 02094, Київ, ул. ГнатаХоткевича 20А

${ }^{2}$ Институт технической теплофизики НАН Украины 03057, Киев, ул. Марии Капнист (Желябова), 2а 
На основании эксплуатачионньх данных двух скважин, пробуренных на территории Международного иентра возобновляемой энергетики, определена энергетическая эффективность использования подземных вод миоценовой водоносного горизонта для получения теплоты и холода в системах теплохладоснабжения жильх домов и зданий общественного назначения. Опьтные скважины расположены на расстоянии 11,5 м друг от друга, глубина которых составляет 50 и 57 м соответственно. При проведении пробных откачек получены основные предварительные эксплуатационные характеристики горизонта. Статический уровень устанавливается на глубине 32,0 $\mathrm{M}$, дебит скважин составляет 2-3 мччас., Начальная темпераmура подземных вод $-12{ }^{\circ} \mathrm{C}$.

Были раскрыты такие водоносные горизонты и комплексы. горизонт аллювиально-делювиальных отложений первой надпойменной террасы, состоящчий из квариевых песков с линзами и прослойками суглинков и залегающий на глубине от 8 до 12 м; водоносный комплекс в отложениях межсгорской, берекской $u$ новопетровской свит олигочен-миоцена (полтавская и харьковская серии), который залегает на глубине от 32 до 50 м и состоит из мелко-зернистого песка; бучакский-каневский водоносный горизонт, залегающчй на глубине от 90 до 117 м u состоящий из мелкого и мелко-зернистого песка.

Для оченки возможности использования подземных вод с целью геотермального тепло- и хладоснабжения использован водоносный горизонт полтавского и харьковского возраста, поскольку этот горизонт изолирован от поверхносmных и грунтовых вод мощуной толщей (до 20 м) плотных глин, обеспечивает ему постоянный режим фильтрачии и стабильные гидрогеологические параметры.

В работе показано, что использование подземных вод как источника низкопотенциальной энергии для тепловых насосов позволяет получить от скважинь в 7...10 раз больше тепловой мошности по сравнению с традиционными теплонасосными системами на основе грунтовых зондов. Предложена схема работы теплонасосных агрегатов со ступенчатым срабатьванием температурного потенциала подземных вод от $+12{ }^{\circ} \mathrm{C}$ до $+1{ }^{\circ} \mathrm{C}$, что позволяет почти в полтора раза повысить энергетическую эффективность прочесса генерирования тепловой энергии. Оценена эффективность применения подземных вод для кондииионирования помешений в летнее время. Показано, что для данных скважси величина СОР прочесса «пассивного» кондиционирования превышает 25. Температуру в помещении можно снизить на 5 градусов. Количество «холода», которое может быть получено от одной скважины, составляет более $10 \kappa \mathrm{Bm}$.

На основании анализа гидрогеологических характеристик и режима фильтраиии первых от поверхности водоносных горизонтов выбран наиболее подходящчий для создания систем геотермального тепло- и хладоснабжения водносный комплекс и проведены расчеты, которые показали иелесообразность использования водоносного горизонта в отложениях межигорской, берекской и новопетровской свит олигоиен-миочена. Библ. 3, табл. 3, рис. 4.

Ключевые слова: подземные воды, тепловой насос, теплоснабжение, хладоснабжение, энергетическая эффективность

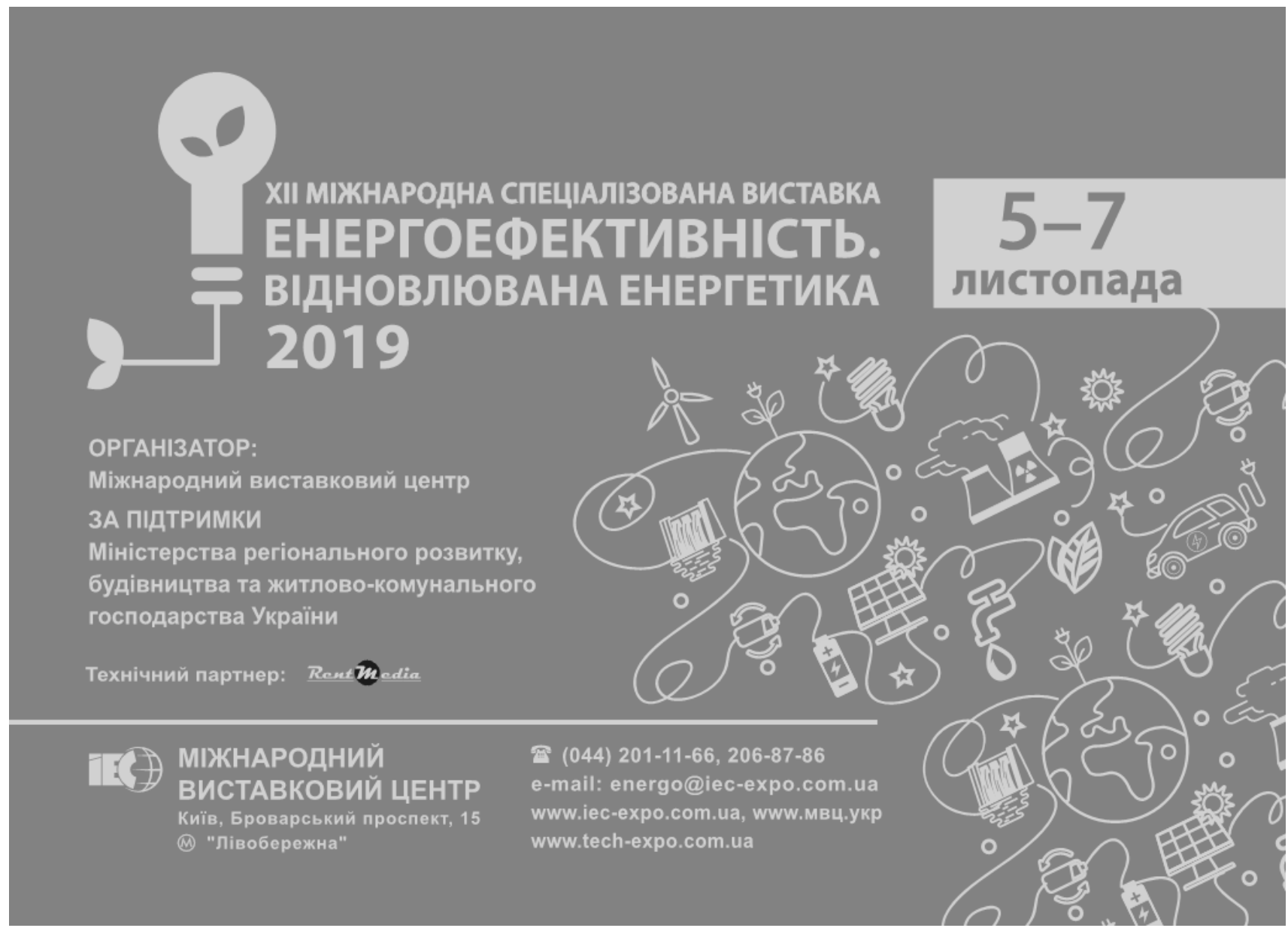

